\title{
Challenges and Opportunities of Finnish Defence Equipment Projects: Changes over a Decade
}

\author{
ILKKA IKONEN \\ National Defence University, Finland \\ ilkka.ikonen@mil.fi \\ LAURI KANANOJA \\ National Defence University, Finland \\ lauri.kananoja@mil.fi \\ JUHA-MATTI LEHTONEN \\ National Defence University, Finland \\ juha-matti.lehtonen@mil.fi
}

The objective of this study is to examine success factors of defence equipment projects in the Finnish Defence Forces. The outline of established success factors for projects and performance measurement is based on the literature review. The strength of this study is that it incorporates a longitudinal design of success factor changes from 2006 to 2018. The main research question is 'How challenges and opportunities of Finnish defence equipment projects have changed from 2006 to 2018?' The results of the empirical data offer a unique opportunity to explore changes over a decade in the Finnish defence equipment projects. The challenges and opportunities of defence equipment projects are determined by theory, swoт analysis and the findings of the research process. In conclusion, the critical success factors have remained unchanged, despite the environmental and organizational changes in the Finnish Defence Forces.

Key words: critical success factors, project management, defence industry, project success

https://doi.org/10.26493/1854-4231.13.227-245

\section{Introduction}

The global economic situation means that nearly all European countries are faced with the need to limit public spending. Limited funds must be focused on where they will deliver most benefit. Every country is still trying their best to keep the country secure and providing Armed Forces with the equipment and capabilities they need to operate in a rapidly changing security environment. Without the right 
equipment Armed Forces cannot fulfil their duties and national interest might be at risk. In this changing security environment, the European Union has taken the first step towards funding defence research and joint capability development by releasing the European Defence Action Plan (EDAP) in 2016. One of the main objectives is to be able to pool national resources with a view to financing joint capability development projects under the umbrella of Permanent Structured Cooperation (PESCO) secretariat by the European Defence Agency (EDA) and the EEAS (European External Action Service), including the European Union Military Staff commission. It is estimated that the EU could be financing $€_{1.5}$ billion per year (EEAS 2018a). In the year $2018 \mathrm{EU}$ agreed to the launching of seventeen defence projects (EEAS 2018b). In 2017 France and Germany decided on the jointly development of a new fighter aircraft in order to replace their existing fleets of rival warplanes. This new fighter should be the European alternative for us F-35. These new fighters are made by Airbus and Dassault and they should be operational in 2035-2040. Finland has launched a defence project that will replace the F/A-18 Hornet multirole combat aircraft in the next decade. Likewise, the Finnish Navy has started a project named 'Fleet 2020' that will include four new battle ships. The estimated cost of these two defence projects is 7-11 billion euros (Puolustusvaliokunta 2017, 10).

Consequently, defence equipment projects can worth billions of euros and new fighter aircrafts can cost hundreds of billions; therefore, successful management and understanding of the rationale behind a project's fail or success are the key elements for delivering efficient and cost-effective projects. The defence equipment projects' success is crucial in an era of decreasing budgets, where nations and governments carefully decide on the allocation of financial resources. Effective procurement and support regarding defence equipment is not a 'nice to have' but an essential part of national defence.

Since the 1960s, researchers have been trying to identify which factors lead to project failure or success (Cooke-Davies 2002, 185). Most of the literature has focused on the private sector, whereas studies on the public sector have been limited. In addition to that, the overwhelming majority of the project literature take the industry delivery project viewpoint instead that of government procurement project. Regarding the field of defence equipment projects, studies are even more limited. Identifying and examining a project's success factors is important for the evaluation and effectiveness of different projects in both the private and public sector (Neilimo and Uusi- 
Rauva 2005). This development starting from the 1980 is known as a New Public Management (Hood 1995, 93).

Since the 1980 os, the public sector has used various measurements of performance regarding organisations and projects. The reason behind this has been the need for reduction in project expenses and increase in quantity and quality of services (Arnaboldi, Azzone, and Savoldelli 2004, 213).

\section{Objectives}

Identifying a project's critical success factors is vital for the understanding of why defence equipment projects may fail or succeed. This paper focuses on the critical success factors of the Finnish Defence Forces' equipment projects from 2006 to 2018. There have been various changes since 2006, including a reduction in budget, setting up a centralized purchasing unit instead of each service purchasing their own equipment and changes in materiel policies, including a transition to мотs (Military off-the-Shelf). One objective is to find out whether time and changes also altered success factors or whether they been unchanged. The critical success factors are also important for the management of project-related performance. Effective management depends on the comprehension of these fundamental factors that can be responsible for the success or failure of a project. Managerial implications/management recommendations of changes imply either a stable or evolving agenda. The objective of this research is to provide management recommendations for future defence material acquisition projects in the Finnish Defence Forces. The main research question is 'How challenges and opportunities of the Finnish defence equipment projects have changed from 2006 to 2018?' The secondary research questions are (1) How are the critical success factors of the Finnish Defence Forces' equipment projects developed from 2006 to 2018? (2) How factors of success and failure in defence equipment projects have developed from 2006 to 2018 ?

\section{Literature Review}

SUCCESS FACTORS AND CRITICAL SUCCESS FACTORS

Early research on the success criteria suggests that the main success factors are based on the so-called 'iron triangle or golden triangle of time, cost and quality' (Atkinson 1999, 338; Westerveld 2003, 412; Howsawi, Eager, and Bagia 2011, 620; Cserháti and Szabó 2014, 613). However, more recently, researchers have suggested that a project's success is far more complex. There are more potential factors that 


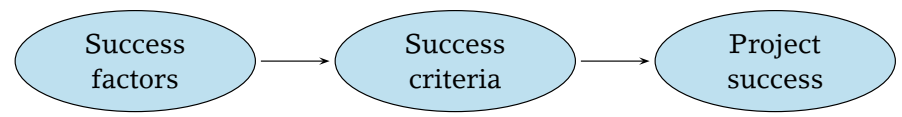

FIGURE 1 Presentation of Critical Success Factors, Success Factors and Success Criteria (adapted from Ikonen 2017, 133)

can be identified. Project management research indicates that it is impossible to have a universal checklist of success factors that applies to all projects. Success factors will be variable in every project (Westerveld 2003, 412; Wateridge 1998, 60; Mir and Pinnington 2014, 203; Cserháti and Szabó 2014, 622). Each project has several variables and each project is unique by nature. Nevertheless, creating a framework for project success help project managers to lead their specific projects to success

There is often some confusion in relation to the terms: success criteria, success factors and critical success factors. Success criteria are used to measure the success, whilst success factors are the set of circumstances or facts that contribute to a project's outcome. Success criteria should be defined at planning phase and beginning of the project (Baccarini 1999, 26). Success factors are the influential forces responsible for failure or success. Critical success factors are part of the success factors (Belassi and Tukel 1996, 146). Critical success factors can be defined as 'things that must be done right if a company wants to be successful' (Ingram et al. 2000, 107) or another definition is 'those inputs to the management system that leads directly or indirectly to the success of the project or business' (Cooke-Davies 2002, 185). Critical success factors include various areas where good performance and skilled management are necessary to ensure the achievement of a project's goals (Fortune and White 2006, 1; Amade et al. 2015, 13).

There is a long tradition of measuring and observing financial success factors such as profitability and cost. Since the late 1990 researchers have published studies on critical factors and have identified several non-financial aspects (Kaplan and Norton 1996, 6-7; Neely et al. 2000, 206; Toivanen 2001, 5). Traditionally most of critical factors have been tangible and physical, like volumes, whereas non-financial factors like employee satisfaction, a skilled manager and good project atmosphere can be described as intangible and non-physical (Lönnqvist 2004). The literature on project management and success, such as success factors and critical success factors is extensive. Fortune and White (2004) identified 63 publications on

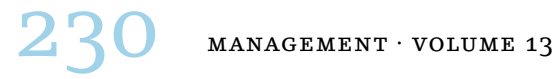


TABLE 1 Critical Success Factors in Literature

\begin{tabular}{llll}
\hline $\begin{array}{l}\text { Pinto and Slevin } \\
\text { (1989) }\end{array}$ & $\begin{array}{l}\text { Fortune and White } \\
(\text { 2004) }\end{array}$ & $\begin{array}{l}\text { Kuan } \\
(\text { 2005) }\end{array}$ & $\begin{array}{l}\text { Gunathilaka, Tuuli, } \\
\text { and Dainty (2013) }\end{array}$ \\
\hline $\begin{array}{l}\text { Top management } \\
\text { support }\end{array}$ & $\begin{array}{l}\text { Support from se- } \\
\text { nior management }\end{array}$ & $\begin{array}{l}\text { Management lead- } \\
\text { ership and support }\end{array}$ & $\begin{array}{l}\text { Top management } \\
\text { support }\end{array}$ \\
\hline Communication & $\begin{array}{l}\text { Good communica- } \\
\text { tion/feedback }\end{array}$ & Culture & $\begin{array}{l}\text { Effective commu- } \\
\text { nication }\end{array}$ \\
\hline $\begin{array}{l}\text { Personnel recruit- } \\
\text { ment }\end{array}$ & $\begin{array}{l}\text { Clear realistic ob- } \\
\text { jectives }\end{array}$ & IT & $\begin{array}{l}\text { Clearly defined } \\
\text { goals and objec- } \\
\text { tives }\end{array}$ \\
\hline $\begin{array}{l}\text { Monitoring and } \\
\text { feedback }\end{array}$ & $\begin{array}{l}\text { Strong/detailed } \\
\text { plan kept up to } \\
\text { date }\end{array}$ & $\begin{array}{l}\text { Strategy and pur- } \\
\text { pose }\end{array}$ & $\begin{array}{l}\text { Project monitor } \\
\text { and feedback }\end{array}$ \\
\hline Client consultation & User involvement & Measurement & $\begin{array}{l}\text { Clients consulta- } \\
\text { tion and involve- } \\
\text { ment }\end{array}$ \\
\hline Technical tasks & $\begin{array}{l}\text { Well allocated re- } \\
\text { sources }\end{array}$ & Resources & $\begin{array}{l}\text { Allocation of suffi- } \\
\text { cient resources }\end{array}$ \\
\hline $\begin{array}{l}\text { Characteristics of } \\
\text { the project leader }\end{array}$ & $\begin{array}{l}\text { Competent project } \\
\text { manager }\end{array}$ & Motivational aids & $\begin{array}{l}\text { Projects manager } \\
\text { competence }\end{array}$ \\
\hline Trouble-shooting & $\begin{array}{l}\text { Skilled/suitable } \\
\text { qualified team }\end{array}$ & $\begin{array}{l}\text { Organisational in- } \\
\text { frastructure }\end{array}$ & $\begin{array}{l}\text { Effective project } \\
\text { team formation }\end{array}$ \\
\hline Client acceptance & $\begin{array}{l}\text { Effective change } \\
\text { management }\end{array}$ & $\begin{array}{l}\text { Processes and ac- } \\
\text { tivities }\end{array}$ & $\begin{array}{l}\text { Financial stability } \\
\text { \& adequate funding }\end{array}$ \\
\hline $\begin{array}{l}\text { Power and politics } \\
\text { Sound basis for } \\
\text { project }\end{array}$ & $\begin{array}{l}\text { Training and edu- } \\
\text { cation }\end{array}$ & $\begin{array}{l}\text { Motivation and in- } \\
\text { centives }\end{array}$ \\
\hline $\begin{array}{l}\text { Environment } \\
\text { events }\end{array}$ & $\begin{array}{l}\text { Good leadership } \\
\text { HRM }\end{array}$ & $\begin{array}{l}\text { Established budget } \\
\text { and monitoring }\end{array}$ \\
\hline Urgency & Realistic schedule & $\begin{array}{l}\text { Strategy and pur- } \\
\text { pose }\end{array}$ & $\begin{array}{l}\text { The level of tech- } \\
\text { nology }\end{array}$ \\
\hline & & & \\
\hline
\end{tabular}

critical success factors and outlined 27 different critical success factors in their article. Other scholars found 11 different critical success factors (Kuan 2005), whereas Pinto and Slevin (1989) identified 12 and Gunathilaka, Tuuli, and Dainty (2013) 21 critical success factors. Critical success factors, project success and success criteria were under intensive research from midgos to late 20oos. The most recent literature hasn't created new theoretical implications (Cserháti and Szabó 2014; Amade at al. 2015; Osei-Kyei and Chan 2015; Patanakul et al. 2016; Aguilani et al. 2017)

In table 1 top management support is a mutual top-ranked critical success factor across all authors. Communication and a competent project manager also rank highly in all but Kuan (2005). Kuan's list appears to be more universal compared to other more detailed 
lists of critical success factor. There are variations in the definition of the factors. In particular the importance of the project manager is defined by factors such as characteristics (Pinto and Slevin 1989) and competence (Fortune and White 2004; Gunathilaka, Tuuli, and Dainty 2013). Hence it is not easy to compare those factors directly and that makes general theory building more challenging.

SUCCESS FACTORS AND CRITICAL SUCCESS FACTORS

IN DEFENCE PROJECTS

A study of defence projects in Israel (Tishler et al. 1996; Lipovetsky et al. 1997) identified several factors that lead to success. Tishler et al. (1996) analysed 110 defence projects completed in Israel starting from the mid-1970s to the mid-1990s. This research identified eight critical success factors regarding defence material projects, of these urgency of need and technological feasibility were found to be unique to defence project environment.

Kwak and Smith (2009) published an article about the risk management of major defence projects in the United States. According to this study, all parties involved in the project should have a risk management strategy and expertise in risk management processes and practices, because complex projects encompass technical, legal and political risks.

The main reason for a defence material project delay, overcoming a project's budget and suspending a project is the failure to recognize the risks. The risks are not acknowledged because a comprehensive risk management plan has not been made, but typically the risks are transferred solely to the supplier. The study acknowledges that eliminating the risks associated with risk management would require a thorough transformation at a ministerial level. However, the study suggests that a way to improve a projects' success would be the training of the project personnel and the formation of a good working environment.

Mazur et al. (2014) researched the Australian defence sector and looked at how project managers 'capacity to interact with stakeholders affects the success of major projects and how a project manager's qualities contribute to the successful management of internal and external stakeholders. The emotional intelligence and cognitive flexibility of project managers, i.e. the ability to change their activities in different environments and situations, were important elements of the development, quality and effectiveness of stakeholder relations, which made the project more successful. On the other hand, systematic thinking, i.e. simultaneous consideration of the interests of

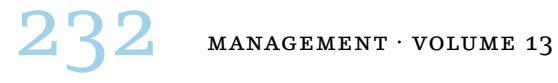


table 2 Critical Success Factors in Defence Projects

\begin{tabular}{|c|c|c|}
\hline Tishler et al. (1996) & $\begin{array}{l}\text { Frinsdorf, Zuo, and Xia } \\
\text { (2014) }\end{array}$ & $\begin{array}{l}\text { Rodriguez-Segura et al. } \\
(2016)\end{array}$ \\
\hline $\begin{array}{l}\text { Senior management's } \\
\text { support }\end{array}$ & $\begin{array}{l}\text { Senior management } \\
\text { support }\end{array}$ & $\begin{array}{l}\text { Project management } \\
\text { Project policies }\end{array}$ \\
\hline Project team adequacy & Communication & Process policy \\
\hline and preparation & Capability of the & Customer-end user \\
\hline Adequacy of the user & organisation & External environment \\
\hline $\begin{array}{l}\text { Leadership of the project } \\
\text { manager }\end{array}$ & $\begin{array}{l}\text { Project scope is } \\
\text { well-defined and }\end{array}$ & \\
\hline Human resources & understood & \\
\hline Management policy & Resources & \\
\hline
\end{tabular}

individuals, groups, project organizations and stakeholders, did not show any connection to the success of stakeholder relationships or projects.

Frinsdorf, Zuo, and Xia (2014) published an article about the effectiveness of defence sector projects. According to this study an effective project is the one where external pressures can be minimized by identifying major delays or obstacles in relation to the project. In order to achieve the project's effectiveness, the defence industry cannot only focus on managing the internal factors of the projects (e.g. clear goal, quality, action cohesion). The external factors of the project (e.g. organizational project portfolio, stakeholder management, project co-operation, organizational culture) should also be considered, so that the project will not be a mere integral part of the organization. In the defence sector, structural factors, such as bureaucracy and security constraints are hampering the success of the projects.

Rodriguez-Segura et al. (2016) published a study on aerospace and defence sector projects that examined 29 major defence material projects. The required level of investment varied from two million to hundreds of millions of dollars. The results of this study indicated that the influence of the customer and the end-user was more weighted on the supplier's future than the supplier's commercial or project management success.

Most of the authors of defence project success factors take the viewpoint of the defence industry and define the success factors from the industry delivery project point of view. Only Kwak and Smith (2009) explicitly take the viewpoint of the procurement project success factors in his study of Department of Defence documents. Also, Tishler et al. (1996) interviewed representatives from both procurement and industry's delivery project, however, without drawing 
any conclusions regarding the possible differences in success factors between the viewpoints.

\section{Methods}

The results of this paper are based on a longitudinal study design, where similar case studies were conducted with a 12-year interval in between by using the same research protocol. This study involved major defence equipment projects where the follow-up study was chosen to correspond to the initial study in terms of content, size and significance in the Finnish Defence Forces. The initial case study conducted in 2006 examined three major defence equipment projects using material from questionnaires, interviews and official project documents. The framework for questionnaires and interviews which was created in stage 1 (figure 1) was based on an extensive systematic literature review of project success and success factors. In the end 38 articles were identified from the literature review. The follow-up case study conducted in 2018 examined five major defence equipment projects by repeating the methodology.

The questionnaires and interviews were directed to managers and owners of the studied projects; twelve project managers or owners gave their insights in the initial study and eleven project managers or owners in the follow-up study. A total of eight case projects was counted for this research. In case studies, there is not an ideal number of cases, but a number between 4 and 10 cases is enough to guarantee the quality of the research (Yin 1984; Eisenhardt 1989). A valid case study method demands a triangulation of the data, as Eisenhardt (1989), Tellis (1997) and Rothbauer (2008) suggest. But in some cases, the data is collected from two or even four different sources (Eisenhardt 1989). In this research the data sources are the initial case study, questionnaires and official documents. During the data-triangulation process, the researchers studied several sources of information to find common elements regarding the subject under research. Data triangulation in this research also involved the verification and analysis of these sources.

The study in 2006 identified various potential factors of success or failure of defence equipment projects as well as elucidating factors through a swот framework. The most critical factors were bundled into four categories and found to be influential for the project's success. The four success factor categories were project team, quality and performance, leadership and resources (Ikonen 2017). The follow-up study repeated the accordingly; various potential factors of success or failure for defence equipment projects were identified

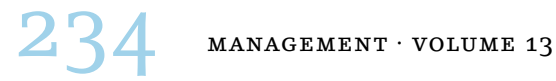




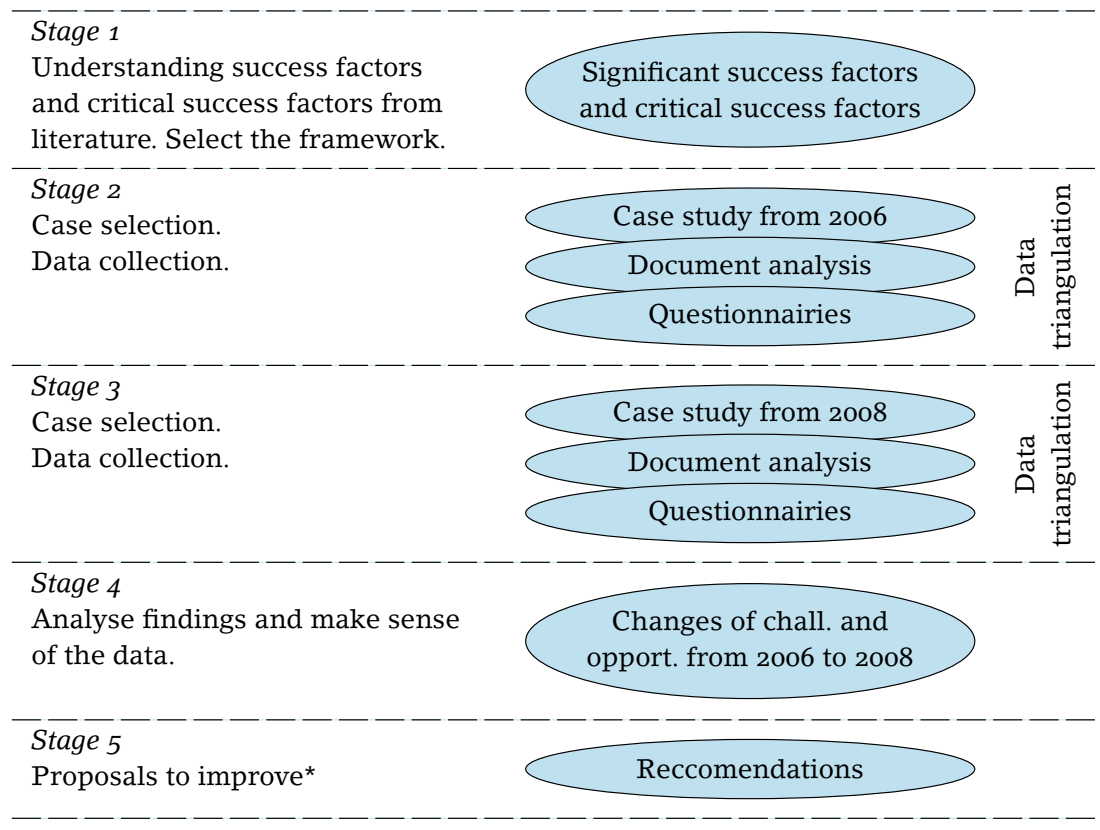

FIGURE 2 The Research Design (* defence material project management practices)

and the most influential factors were bundled into categories. The findings of the follow-up study were compared to the findings of the initial study to illustrate whether the findings add up or differ from one another. All critical success factors were created during the analysis of the first six cases. By this time all the factors were emerged from the data. In the last two cases new data only repeated and enriched the current factors. This is an indication that theoretical saturation was achieved within the eight cases (Eisenhardt 1989). The research design of the study is presented in figure 2 .

\section{Results}

The analysis of the questionnaire and interview data revealed emerging categories of project success factors. These were divided into internal and external factors according to Frinsdorf, Zuo, and Xia (2014). In addition to that they were divided into positive and negative factors. Then these success factors could be placed in a swot matrix similarly to the initial case study. Strengths and weaknesses represent the most influential internal factors in the defence equipment projects' success, whereas opportunities and threats represent a project's external factors. The success factors of each element of 
table 3 Comparison of the swot Matrixes of Defence Equipment Projects Success Factors between the Follow-up Study and the Initial Study

\begin{tabular}{|c|c|c|c|c|}
\hline Item & Strenghts & Weaknesses & Opportunities & Threats \\
\hline Same & $\begin{array}{l}\text { Commitment } \\
\text { of personnel } \\
\text { Meaningful } \\
\text { project }\end{array}$ & $\begin{array}{l}\text { Inadequate } \\
\text { budget Lack of } \\
\text { time }\end{array}$ & & $\begin{array}{l}\text { Political guid- } \\
\text { ance Cuts of } \\
\text { budget Chang- } \\
\text { ing personnel } \\
\text { Changing re- } \\
\text { quirements }\end{array}$ \\
\hline $\begin{array}{l}\text { Similar } \\
\text { meaning }\end{array}$ & $\begin{array}{l}\text { Professionalism } \\
\text { of person- } \\
\text { nel Organized } \\
\text { project group } \\
\text { Permanence } \\
\text { of key person- } \\
\text { nel Support of } \\
\text { management } \\
\text { Defined objec- } \\
\text { tives Industrial } \\
\text { peace }\end{array}$ & $\begin{array}{l}\text { Budget's } \\
\text { supremacy Re- } \\
\text { quirements not } \\
\text { measurable }\end{array}$ & $\begin{array}{l}\text { Final product } \\
\text { Quality control } \\
\text { Co-operation }\end{array}$ & $\begin{array}{l}\text { Failure of the } \\
\text { supplier }\end{array}$ \\
\hline $\begin{array}{l}\text { Follow-up } \\
\text { study }\end{array}$ & $\begin{array}{l}\text { Commercial } \\
\text { know-how } \\
\text { Project experi- } \\
\text { ence Sufficient } \\
\text { number of per- } \\
\text { sonnel }\end{array}$ & $\begin{array}{l}\text { Poorly selected } \\
\text { personnel Sup- } \\
\text { port organiza- } \\
\text { tion }\end{array}$ & $\begin{array}{l}\text { Long-term } \\
\text { planning Use } \\
\text { of referenced } \\
\text { supplier Full- } \\
\text { time key per- } \\
\text { sonnel Possi- } \\
\text { bility to modify } \\
\text { contracts }\end{array}$ & $\begin{array}{l}\text { Delays in de- } \\
\text { livery Inade- } \\
\text { quate contracts } \\
\text { Cultural differ- } \\
\text { ences Effects of } \\
\text { bargained price }\end{array}$ \\
\hline $\begin{array}{l}\text { Initial } \\
\text { study }\end{array}$ & $\begin{array}{l}\text { Limited key } \\
\text { personnel } \\
\text { Project group } \\
\text { cohesion }\end{array}$ & $\begin{array}{l}\text { Product "under } \\
\text { development" } \\
\text { Email manage- } \\
\text { ment Project } \\
\text { manager as ne- } \\
\text { gotiator }\end{array}$ & $\begin{array}{l}\text { Fast and solid } \\
\text { decisions Im- } \\
\text { proved working } \\
\text { technics }\end{array}$ & $\begin{array}{l}\text { Team member } \\
\text { collaboration }\end{array}$ \\
\hline
\end{tabular}

the swoт matrix are listed in table 3. The first row illustrates factors that were found exactly the same in both studies. The second-row lists factors that that were found to be similar to the meaning in both studies. The third row illustrates factors that were found only in the follow-up study. Finally, the fourth-row lists factors that appeared only in the initial study.

According to the participants, the greatest strength of a project lies in its personnel. The personnel of the successful project is to be committed, professional (i.e. capable of taking the project forward), qualified and well-organized and the number of personnel should add up to the project's size and requirements. Management support 
and defined responsibilities are needed to enhance the level of performance of the project group. The commitment of the personnel was considered as a shared strength in defence equipment projects. The initial study did not find previous commercial know-how, project experience or sufficient number of personnel as the main strengths of a project. Furthermore, the follow-up study did not find limited key personnel or project group cohesion to be vital strengths as such.

Both case studies showed that the defence equipment projects' major weaknesses arise from the two tangible dimensions of The Iron Triangle; time and cost. Budget's overruling effect over technical and commercial matters was mentioned several times and undefined responsibilities as well as poorly constructed requirements were found to prevent the project success. Poorly or wrongly selected personnel and the role of organizational support were not experienced as important weaknesses in the initial study. Then again purchasing a product in a development phase (development project), email management and that the project manager becomes a negotiator were not considered as main weaknesses in the follow-up study.

The opportunities identified in both studies were that the final product meets the requirements and that the project recognizes the risks e.g. through the implementation of quality control and mutual co-operation with different project participants. The 2018 data also highlighted the long-term planning as an opportunity to coordinate scarce resources and underlined the importance of selecting a previously referenced supplier in order to avoid unexpected challenges. Furthermore, the possibility of key personnel to contribute to the project full-time without having to perform other duties aside was also mentioned as an important element of success. Fast and solid decision-making and improved working technics were not given emphasis in the most recent study

The supplier failing to deliver the requested final product was considered as the main threat for the project success. Other threats revealed in the data were the influence of political guidance restricting the project, especially during the bidding phase, and delivering unexpected cuts and changes in the budget. Changing personnel and requirements during the project were also mentioned as threats. Delays in the delivery of the end product, inadequate contracts leading to inflexibilities, previously unseen costs cultural differences with the supplier, especially if the supplier is foreign, and possible negative side effects that bargaining may deliver were identified in the 2018 study, while failing collaboration among team members did not emerge as substantial. 
TABLE 4 Comparison of the Factors of Success and Failure in Defence Equipment Projects between the Follow-up Study and the Initial Study

\begin{tabular}{|c|c|c|}
\hline Item & Successful equipment project & Failed equipment project \\
\hline Same & $\begin{array}{l}\text { Realistic time schedule System- } \\
\text { atic documentation plan Interest- } \\
\text { ing project Co-operation among } \\
\text { personnel }\end{array}$ & $\begin{array}{l}\text { Changing and constraining bud- } \\
\text { get Inconsistent political guid- } \\
\text { ance Personnel turnover Non- } \\
\text { documented verbal agreements }\end{array}$ \\
\hline Similar & $\begin{array}{l}\text { Clearly defined objectives Open } \\
\text { interaction between stakeholders } \\
\text { Flexible budget Committed per- } \\
\text { sonnel Measurable requirements } \\
\text { Support from the organization } \\
\text { Personal responsibilities Constant } \\
\text { evaluation }\end{array}$ & $\begin{array}{l}\text { Unrealistic project plan Changing } \\
\text { objectives during project Incom- } \\
\text { petent personnel Failed specifica- } \\
\text { tion of requirements }\end{array}$ \\
\hline $\begin{array}{l}\text { Follow-up } \\
\text { study }\end{array}$ & $\begin{array}{l}\text { Competent and financially stable } \\
\text { supplier Decision-making in the } \\
\text { project level }\end{array}$ & $\begin{array}{l}\text { Insufficient number of personnel } \\
\text { Unskilled supplier }\end{array}$ \\
\hline $\begin{array}{l}\text { Initial } \\
\text { study }\end{array}$ & Good project management & $\begin{array}{l}\text { Too many experts in a project } \\
\text { group Inflexible project manage- } \\
\text { ment Bureaucracy }\end{array}$ \\
\hline
\end{tabular}

The analysis of the data revealed a set of factors that promote a successful or failed equipment project. The factors that are considered to enable project success or causing project to fail are listed in table 4. The first row illustrates factors that were found exactly the same in both studies. The second-row lists factors that that were found to be similar to the meaning in both studies. The third row illustrates factors that were found only in the follow-up study. Finally, the fourth-row lists factors that appeared only in the initial study.

The data summarized in table 4 revealed that a realistic time schedule, systematic documentation plan, co-operation skills of personnel and experience among the personnel recurred unambiguously. Clearly defined project objectives, realistic, feasible and wellstandardized project plan, open and imminent interaction between different stakeholders of the project, secure and flexible budgeting and committed personnel were found to be similar in both studies when considering project success. Furthermore, a successful equipment project should have carefully written and measurable requirements together with a qualified personnel with personal responsibilities. What was interesting was that the data of the follow-up study pointed out the need for a competent, financially stable and referenced supplier, whereas the initial study did not emphasize on the role of the supplier as such. Good project management was found to be a direct success factor in the initial study but considered as 


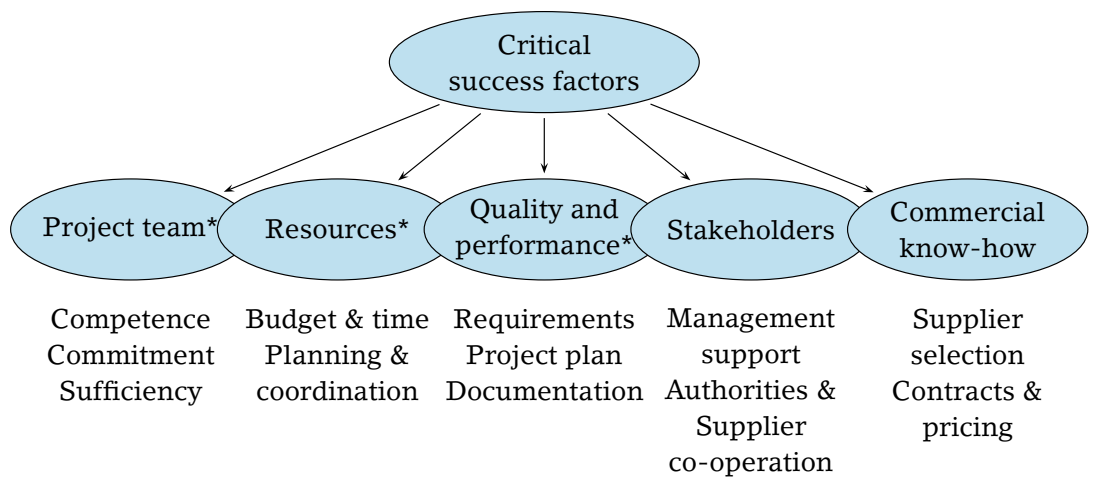

FIGURE 3 Critical Success Factors in Defence Equipment Projects

( ${ }^{*}$ categories found in both case studies)

an integrated, embedded part of other factors in the follow-up study.

Changes and constraints in budget, inconsistent political guidance, tight or unrealistic time schedule, personnel turnover and making an agreement were only verbally repeated in the data. Unrealistic project planning, changing the objectives during the project, incompetent personnel and failed specification of requirements were perceived as failing factors. The study in 2018 pointed out as a threat when the number of personnel does not add up to the size and requirements of a project. The role of the supplier was brought up again by indicating that a failed equipment project has an unskilled supplier - a factor that was not emphasized in the initial study. What was then again missing in the follow-up study compared to the initial study was that a failed equipment project involves too many experts in a project group and that makes cooperation among experts more challenging, together with inflexible project management and too much overall bureaucracy.

Of those success factors found in tables 3 and 4 a total of 13 were assessed to be critical success factors i.e. appeared most often. This is one more compared to the study in 2006. Once the critical success factors were found, they were grouped into categories in order to build a critical success factor framework. A total of five categories were found in the follow-up study which results in one extra category compared to initial study. Project team, resources as well as quality and performance categories appeared identically in both studies. Stakeholders and commercial know-how were identified as new critical success factors categories, whereas leadership, as an independent category, disappeared (figure 3). 
In the initial study (see Ikonen 2017) the people of the project, an open environment and good atmosphere were grouped as critical success factors under the project team category. However, in the follow-up study the project team category involved competence, commitment and sufficiency of personnel as critical success factors. Resources repeated similarly, though planning and coordination were emphasized over an efficient use of resources. Quality and performance were repeated identically. A category of stakeholders involves critical success factors of support from the management and conversational co-operation with not only management but also authorities and suppliers. Furthermore, a category of commercial know-how is divided into supplier selection, contracting and pricing issues. The leadership category's critical success factors such as a good project manager, clear objectives and support from superiors were embedded into other success factors.

\section{Discussion}

The case studies conducted similarly in 2006 and 2018 revealed that the biggest challenge of defence equipment projects has been the inadequate resources especially in terms of time and budget. As the resources are expected to gradually decrease, it is obvious that a project's ability to use the given scarce resources will be highlighted in the future. Another challenge present in the study is inconsistent political guidance that may restrict a projects' ability to achieve its objectives. The study highlights the necessity of qualified, sufficient, committed and carefully chosen personnel. In the Finnish Defence Forces' equipment projects there is a growing need for commercial know-how and conversational stakeholder co-operation among authorities, management and suppliers.

Regarding the results of the 2006 and 2018 studies, the most important changes are the increased significance of adequate resources and the delivery capability of the supplier while the importance of project management is not mentioned as such. This may indicate the increased project management competencies through e.g. project education and training. The Finnish Defence Forces have started to educate personnel for project management more intensively. It is recommended that the education of project management and commercial dimension will be increased further since we regard it as the best way to answer to the challenge of decreasing budgets and increasing costs of defence equipment projects. Nevertheless, the majority of the critical success factors have remained unchanged between 2006 and 2018 despite the organizational and procedural 
changes during that period. These critical success factors are more durable and are not situational or project specific

The environment has changed rapidly due to the growing need of both financial and process-related efficiency. The Finnish Defence Forces organization has been revised in the early 2010 and there has been a transition within materiel politics from developing projects to purchasing already tested, validated products (мотs), and setting up a centralized purchasing unit. We argue that the changes in success factors found in the longitudinal design could relate to environmental and organizational changes. On the other hand, it is possible that there are reliability issues e.g. in classifying the questionnaire data. However, the reliability is strengthened by congruence since the research methods used in both case studies were similar to each other. The reliability may on the other hand be weakened to some degree due to subjectivity and continuity issues. For example, the follow-up study did not find project manager as a critical success factor as such, but it cannot be argued that the impact of project manager has been decreased.

\section{Conclusions}

Many project success factors like top management support (Pinto and Slevin 1989; Fortune and White 2006; Kuan 2005; Gunathilaka, Tuuli, and Dainty 2013; Tishler et al. 1996; Frinsdorf, Zuo, and Xia 2014; Rodriguez-Segura et al. 2016; Aguilani et al. 2017), clear and realistic objectives (Fortune and White 2006; Gunathilaka, Tuuli, and Dainty 2013; Frinsdorf, Zuo, and Xia 2014; Rodriguez-Segura et al. 2016), allocation of resources (Fortune and White 2006; Kuan 2005; Gunathilaka, Tuuli, and Dainty 2013; Frinsdorf, Zuo, and Xia 2014) and competence of the project manager (Pinto and Slevin 1989; Tishler et al. 1996; Fortune and White 2006; Gunathilaka, Tuuli, and Dainty 2013; Mir and Pinnington 2014) and the project team (Fortune and White 2006; Gunathilaka, Tuuli, and Dainty 2013; Cserháti and Szabó 2014; Rodriguez-Segura et al. 2016; Aguilani et al. 2017) are reported in our study, however the viewpoint of procurement alters these perceptions. For example, failure to meet the final user expectations and customer project team preparation (Rodriguez-Segura et al. 2016) do not appear as defence equipment success factors since the final user and customer is the project organization itself. Nor does client consultation, trouble-shooting and client acceptance (Pinto and Slevin 1989), effective management change (Fortune and White 2006; Aguilani et al. 2017), motivational aids or culture (Kuan 2005; Aguilani et al. 2017) appear as such. The clearest distinction

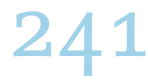


between defence equipment projects and industry delivery projects this paper illustrates is that the defence equipment projects are of procurement nature whereas industry delivery projects operate as production or manufacturing projects. In other words, the defence equipment projects viewpoint differs from that of companies. Accordingly, the viewpoint success factors perceived in the defence equipment context differ.

It is to noted, though, that it may be difficult to compare different lists of success factors and critical success factors between one another, since there is no solid universal definition of concepts. The lack of definitions may cause terminology issues and for that reason one word may be interpreted differently by authors and researchers.

As the literature review reveals, most of the success factor studies focus on industry delivery projects, whereas procurement projects like defence equipment projects are rarely distinctively explored. Studies of possible differences between the procurement and industry delivery projects' success and critical success factors are rare and this study offers an opportunity for further research

As indicated in the literature review, it is impossible to illustrate such success factors that fit into every project at any given time. It may be that projects with virtually identical settings experience different success factors from one another. At the opposite extreme it could be stated that a proper definition of success cannot be given. The question under discussion is why to explore success, success factors or criteria in the first place? Even if we have not found the philosopher's stone, our results contribute to the discussion of perceived success in defence equipment projects and to distinguish the defence equipment projects from projects in the private sector and within industries.

\section{References}

Aquilani, B., C. Silvestri, A. Ruggieri, and C. Gatti. 2017. 'A Systematic Literature Review on Total Quality Management Critical Success Factors and the Identification of New Avenues of Research.' The TQм Journal, 29 (1): 184-213.

Amade, B., E. C. Ubani, E. O. M. Omajeh, and U. A. P. Njoku. 2015. 'Critical Success Factors for Public Sector Construction Project Delivery: A Case of Owerri, Imo State.' International Journal of Research in Management, Science and Technology 3 (1): 11-21.

Arnaboldi, M., G. Azzone, and A. Savoldelli. 2004. 'Managing a Public Sector Project: The Case of the Italian Treasury Ministry.' International Journal of Project Management 22 (3): 213-23.

Atkinson, R. 1999. 'Project Management: Cost, Time and Quality, Two

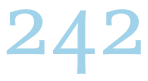

MANAGEMENT $\cdot$ VOLUME 13 
Best Guesses and a Phenomenon, Its Time to Accept Other Success Criteria.' International Journal of Project Management 17 (6): 337-42.

Baccarini, D. 1999. 'The Logical Framework Method for Defining Project Success.' Project Management Journal 30 (4): 25-32.

Belassi, W., and O. I. Tukel. 1996. 'A New Framework for Determining Critical Success/Failure Factors in Projects.' International Journal of Project Management 14 (3): 141-51.

Cooke-Davies, T. 2002. 'The "Real" Success Factors on Projects.' International Journal of Project Management 20 (3): 185-90.

Cserháti, G., and L. Szabó. 2014. 'The Relationship between Success Criteria and Success Factors in Organisational Event Projects.' International Journal of Project Management 32 (4): 613-24.

EEAS. 2018a. 'Defending Europe: European Defence Fund.' https://eeas .europa.eu/sites/eeas/files/defence_fund_factsheet_o_o.pdf

- 2018b. 'Permanent Structured Cooperation: Pesco Deepening Defence Cooperation among Eu Member States.' https://eeas.europa .eu/sites/eeas/files/pesco_factsheet_09-03-2018_o.pdf

Eisenhardt, K. M. 1986. 'Building Theories from Case Study Research.' The Academy of Management Review 14 (4): 532-50.

Frinsdorf, O., J. Zuo, and B. Xia. 2014. 'Critical Factors for Project Efficiency in a Defence Environment.' International Journal of Project Management 32 (5): 803-14.

Fortune, J., and D. White. 2006. 'Framing of Project Critical Success Factors by a Systems Model.' International Journal of Project Management 24 (1): 53-65.

Gunathilaka, S., M. M. Tuuli, and A. R. J. Dainty. 2013. 'Critical Analysis of Research on Project Success in Construction Management Journals.' Paper presented at the 29th Annual ARcom Conference, Nottingham, 2-4 September.

Hood, C. 1995. 'The “New Public Management" in the 1980s: Variations on a Theme.' Accounting, Organizations and Society 20 (2-3): 93-109.

Howsawi, E. M., D. Eager, and R. Bagia. 2011. 'Understanding Project Success: The Four-Level Project Success Framework.' Paper presented at the 2011 IEEE International Conference, Singapore, 6-9 December.

Ikonen, I. 2017. 'Critical Success Factors of Defence Equipment Projects.' Paper presented at the 6th International Scientific Conference on Project Management in the Baltic Countries, Riga, 27-8 April.

Ingram, H., K. Biermann, J. Cannon, J. Neil, and C. Waddle. 20oo. 'Internalizing Action Learning: A Company Perspective; Establishing Critical Success Factors for Action Learning Courses.' International Journal of Contemporary Hospitality Management 12 (2): 107-14.

Kaplan, R., S, and D. P. Norton. 1996. 'The Balanced Scorecard: Translating Strategy into Action.' Boston, BA: Harvard Business Scholl Press.

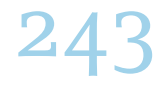


Kuan, Y. W. 2005. 'Critical Success Factors for Implementing Knowledge Management in Small and Medium Enterprises.' Industrial Management and Data Systems 105 (3): 261-79.

Kwak, Y. H., and B. M. Smith. 2009. 'Managing Risks in Mega Defence Acquisition Projects: Performance, Policy, and Opportunities.' International Journal of Project Management 27 (8): 812-20.

Lipovetsky, S., A. Tishler, D. Dvir, and A. Shenhar. 1997. 'The Relative Importance of Project Success Dimensions.' R\&D Management 27 (2): 97-106.

Lönnqvist, A. 2004. Measurement of Intangible Success Factors: Case Studies on the Design, Implementation and Use of Measures. Tampere: Tampere University of Technology.

Mazur, A., A. Pisarski, A. Chang, and N. M. Ashkanasy. 2014. 'Rating Defence Major Project Success: The Role of Personal Attributes and Stakeholder Relationships.' International Journal of Project Management 32 (6): 944-57.

Mir, F. A., and A. H. Pinnington. 2014. 'Exploring the Value of Project Management: Linking Project Management Performance and Project Success.' International Journal of Project Management 32 (2): 20217.

Neely, A., J. Mills, K. Platts, H. Richards, M. Gregory, M. Bourne, and M. Kennerley. 2000. 'Performance Measurement System Design: Developing and Testing a Process-Based Approach.' International Journal of Operations \& Production Management 20 (10): 1119-45.

Neilimo, K., and E. Uusi-Rauva. 1997. Johdon laskentatoimi. Helsinki: Edita.

Osei-Kyei, R., and A. P. Chan. 2015. 'Review of Studies on the Critical Success Factors for Public-Private Partnership (PPP) Projects from 1990 to 2013.' International Journal of Project Management 33 (6): 1335-46.

Patanakul, P., Y. H. Kwak, O. Zwikael, and M. Liu. 2016. 'What Impacts the Performance of Large-Scale Government Projects?' International Journal of Project Management 34 (3): 452-66.

Piercy, N., and W. Giles. 1989 'Making swoт Analysis Work.' Marketing Intelligence \& Planning 7 (5-6): 5-7.

Pinto, J. K., and D. P. Slevin. 1989. 'Critical Success Factors in R\&D Projects.' Research Technology Management 32 (1): 31-5.

Puolustusvaliokunta. 2017. 'Valiokunnan mietintö PUVM 4/2017.' https:// www.eduskunta.fi/FI/vaski/Mietinto/Documents/PuVM_4+2017.pdf

Rodriguez-Segura, E., I. Ortiz-Marcos, J. J. Romero, and J. Tafur-Segura. 2016. 'Critical Success Factors in Large Projects in the Aerospace and Defense Sectors.' Journal of Business Research 69 (11): 5419-25.

Rothbauer, P. 2008. 'Triangulation.' In The SAGE Encyclopedia of Qualitative Research Methods, edited by Lisa M. Given, 1:892-4. Thousand Oaks, cA: California.

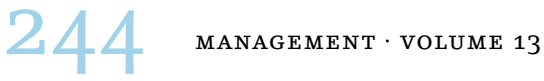


Tellis, W., M. 1997. 'Application of a Case Study Methodology.' The Qualitative Report 3 (3), 1-19.

Tishler, A., D. Dvir, A. J. Shenhar, and S. Lipovetsky. 1996. 'Identifying Critical Success Factors in Defense Development Projects: A Multivariate Analysis.' Technological Forecasting and Social Change 51 (2): 151-71.

Toivanen, J. 2001. Balanced Scorecard in implementointi ja käytön nykytila Suomessa. Acta Universatis Lappeenrantaensis 108. Lappeenranta: Lappeenrannan teknillinen korkeakoulu.

Wateridge, J. 1998. 'How Can Is/Iт Projects be Measured for Success?' International Journal of Project Management 16(1): 59-63.

Westerveld, E. 2003. 'The Project Excellence Model? Linking Success Criteria and Critical Success Factors.' International Journal of Project Management 21 (6): 411-8.

Yin, R. K. 1984. Case Study Research: Design and Methods. Applied Social Research Methods Series 5. London: Sage.

This paper is published under the terms of the Attribution-

NonCommercial-NoDerivatives 4.o International (CC BY-NC-ND 4.0)

License (http://creativecommons.org/licenses/by-nc-nd/4.o/). 